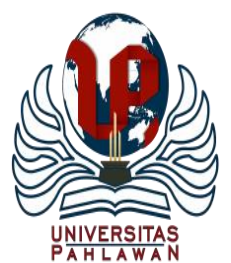

Edukatif : Jurnal Ilmu Pendidikan Volume 3 Nomor 4 Tahun 2021 Halm 1409 - 1417

EDUKATIF: JURNAL ILMU PENDIDIKAN

Research \& Learning in Education

https://edukatif.org/index.php/edukatif/index

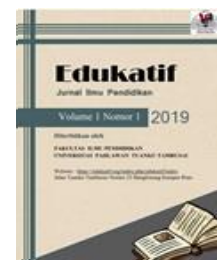

\title{
Pengaruh Kreativitas Guru Dalam Pembelajaran Daring Terhadap Hasil Belajar Siswa Pada Mata Pelajaran Pendidikan Agama Islam
}

\author{
Suhendra $^{1}$, Dian Nurbaeti ${ }^{2 凶}$, Syarifah Gustiawati ${ }^{3}$ \\ Universitas Ibn Khaldun, Indonesia ${ }^{1,2,3}$ \\ E-mail : $\underline{\text { dr.suhendra.mm@gmail.com }}{ }^{1}, \underline{\text { diannurbaeti99@gmail.com }}^{2}$, syarifah@ afai.uika-bogor.ac.id ${ }^{3}$
}

\begin{abstract}
Abstrak
Salah satu masalah yang dihadapi oleh guru dalam pembelajaran daring adalah menumbuhkan kreativitas guru dalam proses belajar mengajar. Penelitian ini bertujuan untuk mengukur atau menganalisis apakah terdapat pengaruh yang signifikan antara kreativitas guru dalam pembelajaran daring terhadap hasil belajar siswa kelas VI SD pada mata pelajaran Pendidikan Agama Islam di SDN Kedung Waringin Bogor. Metode penelitian yang digunakan adalah metode penelitian kuantitatif korelasional, mengumpulkan data berupa angka-angka melalui instrumen penelitian dan menganalisisnya menggunakan statistik. Hasil analisis data penelitian menunjukkan bahwa terdapat pengaruh yang signifikan antara kreativitas guru dalam pembelajaran daring terhadap hasil belajar siswa kelas VI pada mata pelajaran Pendidikan Agama Islam, dengan nilai $r_{x y}>r_{\text {tbel }}$ dengan taraf signifikansi 5\% dan df $=68$, yaitu $0,406>0,250$. Dan pengaruh kreativitas guru dalam pembelajaran daring terhadap hasil belajar siswa, dari hasil perhitungan $t_{\text {hitung }}$ menunjukkan bahwa nilai $t_{\text {hitung }}$ $>\mathrm{t}_{\text {tabel }}$ pada $\alpha=0,05$ yaitu 3,663 >1,667. Hal ini menunjukkan bahwa "terdapat pengaruh yang signifikan antara kreativitas guru dalam pembelajaran daring terhadap hasil belajar siswa".
\end{abstract}

Kata Kunci: pembelajaran daring, kreativitas guru, hasil belajar.

\section{Abstract}

One of the obstacles faced in online learning is foresting teacher creativity in the teaching and learning process. This research aims to measure or analyze whether there is a significant influence between teacher creativity in online learning on the learning outcomes of grade VI elementary school students in Islamic education subjects in public elementary schools Kedung Waringin Bogor. The research method used is correlational quantitative research methods, collect data in the form of numbers through research instruments and analyze it using statistics. The results of the research data analysis show that there is a significant influence between teacher creativity in online learning on student learning outcomes of grade VI elementary school students in Islamic education, with value $r_{x y}>r t_{a b e l}$ with a level of significance $5 \%$ and $d f=68$, that is $0,406>$ 0,250. And the influence of teacher creativity in online learning on student learning outcomes, from the calculation result thitung indicates that the value $t_{\text {hitung }}>t_{\text {tabel }}$ at $\alpha=0,05$ that is 3,663 $>1,667$. This shows that "there is a significant influence between teacher creativity in online learning on student learning outcomes".

Keywords: online learning, teacher cretivity, learning outcomes.

Copyright (c) 2021 Suhendra, Dian Nurbaeti, Syarifah Gustiawati

$\triangle$ Corresponding author:

Email : diannurbaeti99@gmail.com

DOI : https://doi.org/10.31004/edukatif.v3i4.568

ISSN 2656-8063 (Media Cetak)

ISSN 2656-8071 (Media Online)

Edukatif : Jurnal Ilmu Pendidikan Vol 3 No 4 Tahun 2021 p-ISSN 2656-8063 e-ISSN 2656-8071 
1410 Pengaruh Kreativitas Guru Dalam Pembelajaran Daring Terhadap Hasil Belajar Siswa Pada Mata Pelajaran Pendidikan Agama Islam - Suhendra, Dian Nurbaeti, Syarifah Gustiawati

DOI: https://doi.org/10.31004/edukatif.v3i4.568

\section{PENDAHULUAN}

Pembelajaran daring adalah pembelajaran jarak jauh yang dilakukan tanpa tatap muka dengan memanfaatkan internet menggunakan aplikasi pembelajaran maupun jejaring sosial. "Pembelajaran daring atau online learning merupakan pembelajaran jarak jauh dengan menggunakan perangkat komputer atau gawai yang saling berhubungan satu sama lain di mana guru dan siswa berkomunikasi secara interaktif dengan memanfaatkan media komunikasi dan informasi" (Fahrina et al., 2020).

Berdasarkan kebijakan pemerintah dalam surat edaran Nomor 4 Tahun 2020 tentang Pelaksanaan Kebijakan Pendidikan dalam Masa Darurat Penyebaran Corona Virus Disease (COVID-19), pembelajaran dilaksankan secara daring atau online. Hal ini dilakukan guna mencegah dan menghindari penyebaran Covid19 yang tengah melanda di berbagai negara termasuk Indonesia. Sistem pembelajaran daring yang dilakukan adalah sistem kegiatan belajar mengajar tanpa tatap muka secara langsung antara guru dan peserta didik tetapi dilakukan secara online menggunakan jaringan internet. Oleh karena itu pada masa pandemi Covid-19 saat ini pendidikan menjadi aspek yang penting untuk dilihat bagaimana perkembangannya demi meningkatkan taraf pendidikan (Nafrin \& Hudaidah, 2021).

Di Indonesia, pembelajaran jarak jauh atau daring ini dimulai pada tanggal 16 Maret 2020, dimana anak mulai belajar dari rumahnya masng-masing tanpa perlu pergi ke sekolah. Berbicara mengenai jarak jauh atau daring maka pentingnya penguasaan ilmu teknologi bagi seorang guru agar pembelajaran jarak jauh tetap berjalan dengan efektif disaat pandemi seperti ini (Yunitasari \& Hanifah, 2020).

Salah satu masalah yang dihadapi oleh guru dalam pembelajaran daring adalah menumbuhkan kreativitas guru dalam proses belajar mengajar. Dalam pembelajaran daring, kreativitas guru sangat diperlukan agar siswa tetap semangat meskipun pembelajaran dilakukan secara jarak jauh. Peranan kreativitas guru tidak hanya sekedar membantu proses belajar mengajar dengan mencakup satu aspek dalam diri peserta didik saja, akan tetapi mencakup aspek-aspek lainnya yaitu kognitif, psikomotorik dan afektif. Oleh karena itu, nilai keunggulan yang harus dimiliki guru adalah kreativitas. Sebagai seorang pendidik khususnya pada jenjang SD, guru harus mampu tetap menjadi tauladan bagi peserta didik serta tetap memperhatikan aspek dan tujuan pembelajaran yang sesungguhnya. "Kreativitas dapat diartikan sebagai suatu usaha kemampuan berpikir sesuatu dengan cara yang baru dan langka, serta menghasilkan penyelesaian yang unik. Kreativitas dalam pribadi mencerminkan keunikan individu dalam berpikir dan mengungkapkan sesuatu" (Anwar, 2018).

Adapun dalil yang membahas tentang kreativitas terdapat di dalam Al-Qur'an surah Ar-Ra'du ayat 11, yaitu:

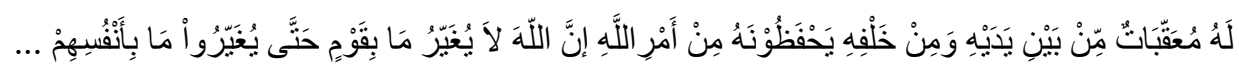

Artinya: "Baginya (manusia) ada malaikat-malaikat yang selalu menjaganya bergiliran, dari depan dan belakangnya. Mereka menjaganya atas perintah Allah. sesungguhnya Allah tidak mengubah keadaan suatu kaum sebelum mereka mengubah keadaan mereka sendiri. ..."

Dalam tafsir Fi Zhilalil-Qur'an dikatakan ayat ini menjelaskan bahwa Allah selalu mengikuti mereka dengan memerintahkan malaikat-malaikat penjaga untuk mengawasi apa saja yang dilakukan manusia untuk mengubah diri dan keadaan mereka, yang nantinya Allah akan mengubah kondisi mereka itu. Sebab, Allah tidak akan mengubah nikmat atau bencana, kemuliaan atau kerendahan, kedudukan atau kehinaan kecuali jika orang-orang itu mau mengubah perasaan, perbuatan, dan kenyataan hidup mereka. Maka Allah akan mengubah keadaan diri mereka sesuai dengan perubahan yang terjadi dalam diri dan perbuatan mereka sendiri.

Pada masa pandemi COVID-19 ini guru dituntut untuk tetap dapat melaksanakan pembelajaran dua arah secara inovatif tanpa memberatkan atau membebani peserta didik. Pendidik yang merasa terbebani dengan pembelajaran daring sejatinya karena belum matangnya bekal yang dimiliki dan minimnya pengetahuan tentang teknologi dan komunikasi dalam pembelajaran. Namun pada pelaksanaannya, guru terkendala pada 
1411 Pengaruh Kreativitas Guru Dalam Pembelajaran Daring Terhadap Hasil Belajar Siswa Pada Mata Pelajaran Pendidikan Agama Islam - Suhendra, Dian Nurbaeti, Syarifah Gustiawati

DOI: https://doi.org/10.31004/edukatif.v3i4.568

tingkat penguasaan teknologi. Sebagian besar pengajar belum bisa meninggalkan metode konvensional yang selama ini sudah mengakar, dan tidak mengikuti perkembangan zaman untuk mengembangkan dan memperbaharui metode, pengetahuan, dan keterampilan teknologi untuk mendukung proses pendidikan jarak jauh (Fahrina et al., 2020).

"Tujuan utama kreativitas adalah menjalankan perintah-Nya dan menjauhi larangan-Nya dalam rangka mencapai ridho-Nya. Inilah yang menjadi motivasi umat muslim dalam menciptakan dan menghasilkan sesuatu" (Dimyati, 2019). Sebagaimana yang tertuang di dalam Q.S Adz-Dzariyat ayat 56:

$$
\text { وَمَا خَلَقُتُ الْجِنَّ وَالإنْسَ إِلاًَ لِيَعْبُدُوْنَ }
$$

"Dan Aku tidak menciptakan jin dan manusia melainkan supaya mereka menyembah-Ku".

Sebagai solusi dalam rangka meningkatkan hasil belajar siswa dan menuntaskan kendala dalam pembelajaran daring, guru harus mau dan mampu memanfaatkan aplikasi yang ada sebagai upaya pelaksanaan sistem pembelajaran daring. Guru harus melakukan metode-metode baru demi meningkatkan kualitas bahan ajar dengan membuat variasi baru, agar tidak terjadi kejenuhan dalam melaksanakan pembelajaran daring. Kreativitas mengajar guru dalam suatu pembelajaran sangat berpengaruh terhadap pemahaman peserta didik. Dengan demikian kreativitas guru sangat diperlukan untuk mewujudkan tujuan pendidikan. Seorang guru merupakan jembatan profesional yang terkait langsung di dalam dunia pendidikan dan berinteraksi dengan peserta didik dalam kesehariannya (Oktaria \& Jaenudin, 2017).

Dalam proses belajar dan mengajar, kreatifitas dalam pembelajaran merupakan bagian dari suatu sistem yang tak terpisahkan dengan terdidik dan pendidik. Peranan kreatifitas guru tidak sekedar membantu proses belajar mengajar dengan mencakup satu aspek dalam diri manusia saja, akan tetapi mencakup apek-aspek lainnya yaitu kognitif, psikomotorik dan afektif. Secara umum kreatifitas guru memiliki fungsi utama yaitu membantu menyelesaikan pekerjaannya dengan cepat dan efisien. Adapun pentingnya kreativitas guru dalam pembelajaran antara lain: (1) Kreatifitas guru berguna dalam transfer informasi lebih utuh, (2) Kreatifitas guru berguna dalam merangsang siswa untuk lebih berpikir secara ilmiah dalam mengamati gejala masyarakat atau gejala alam yang menjadi objek kajian dalam belajar, (3) Produk kreatifitas guru akan merangsang kreatifitas siswa (Oktavia, 2014).

Kreativitas diartikan sebagai kemampuan guru menciptakan ide-ide baru maupun karya baru sebagai upaya untuk menemukan solusi atas permasalahan yang dihadapi dalam menjalankan profesinya di bidang pendidikan terutama pada kegiatan pembelajaran (Ambarita \& Yuniati, 2021). Kreativitas diartikan sebagai kemampuan untuk menciptakan suatu produk baru, baik yang benar-benar baru sama sekali maupun yang merupakan modifikasi atau perubahan dengan mengembangkan hal-hal yang sudah ada. Bila hal ini dikaitkan dengan kreativitas guru, guru yang bersangkutan mungkin menciptakan suatu strategi mengajar yang benarbenar baru dan orisinil (asli ciptaan sendiri), atau dapat saja merupakan modifikasi dari berbagai strategi yang ada sehingga menghasilkan bentuk baru. Mengajar bukan lagi usahamenyampaikan ilmu pengetahuan, melainkan usaha menciptakan sistem lingkungan yang membelajarkan peserta didik agar tujuan pengajaran dapat tercapai secara optimal. Mengajar dalam pemahaman ini memerlukan suatu strategi yang tepat bagi tujuan yang ingin dicapai untuk itu perlu dibina dan dikembangkan kreativitas guru dalam mengelola program pengajaran dengan strategi belajar mengajar dengan berbagai variasi (Pentury, 2017).

Untuk mengembangkan kreativitas dalam pembelajaran, maka perlu diketahui ciri- ciri kepribadian kreatif yang perlu dimunculkan baik oleh guru maupun siswa. Adapun ciri-ciri pribadi yang kreatif menurut Munandar adalah: imajinatif, mempunyai prakarsa, mempunyai minat luas, mandiri dalm berpikir, rasa ingin tahu, senang bertualang, penuh energi, percaya diri, bersedia mengambil resiko, dan berani dalam pendirian dan keyakinan (Murdiana et al., 2020).

Purwanto mengemukakan, hasil belajar sering kali digunakan sebagai ukuran untuk mengetahui seberapa jauh seseorang menguasai bahan yang sudah diajarkan. Hasil belajar dapat dijelaskan dengan 
1412 Pengaruh Kreativitas Guru Dalam Pembelajaran Daring Terhadap Hasil Belajar Siswa Pada Mata Pelajaran Pendidikan Agama Islam - Suhendra, Dian Nurbaeti, Syarifah Gustiawati

DOI: https://doi.org/10.31004/edukatif.v3i4.568

memahami dua kata yang membentuknya, yaitu "hasil" dan "belajar". Pengertian hasil menunjukan pada suatu perolehan akibat dilakukannya suatu aktivitas atau proses yang mengakibatkan berubahannya input secara fungsional, sedangkan belajar dilakukannya untuk mengusahakan adanya perubahan perilaku pada individu yang belajar (Fitrianingtyas \& Radia, 2017).

Hasil belajar sering disebut dengan istilah scholastic achievement atau academic achievement yaitu seluruh kecakapan dan hasil yang dicapai melalui proses belajar mengajar di sekolah yang dinyatakan dengan angka-angka atau nilai-nilai berdasarkan tes hasil belajar (Sutrisno, 2021). Hasil belajar siswa tidaklah semuanya sama, ada siswa yang mendapat hasil memuaskan dan adapula yang hasilnya tidak memuaskan. Ini tidak terlepas dari cara, metode, dan model pembelajaran yang digunakan seorang guru untuk memaparkan pelajaran yang diberikan. Cara, metode, dan model pembelajaran tersebut harus dibuat semenarik mungkin agar siswa tertarik dengan pelajaran yang diberikan (Syahputra, 2020). Yang mempengaruhi hasil belajar menyangkut faktor internal dan faktor eksternal. Faktor internal (faktor dari dalam diri manusia itu sendiri) yang meliputi faktor psikologi. Sedangkan faktor eksternal (faktor dari luar manusia) meliputi faktor non sosial dan faktor sosial (Wahyuningsih, 2020).

Berdasarkan latar belakang permasalahan di atas, peneliti tertarik untuk melakukan penelitian ini dengan mengangkat topik "Pengaruh kreativitas guru dalam pembelajaran daring terhadap hasil belajar siswa kelas VI pada mata pelajaran Pendidikan Agama Islam". Maka rumusan masalah dalam penelitian ini adalah: Apakah terdapat pengaruh yang signifikan antara kreativitas guru dalam pembelajaran daring terhadap hasil belajar siswa kelas VI SD pada mata pelajaran pendidikan agama Islam di SDN Kedung Waringin Bogor?

Tujuan penelitian ini ialah untuk mengetahui apakah ada pengaruh yang signifikan antara kreativitas guru dalam pembelajaran daring terhadap hasil belajar siswa kelas VI SD pada mata pelajaran pendidikan agama Islam di SDN Kedung Waringin Bogor.

\section{METODE PENELITIAN}

Penelitian ini termasuk penelitian kuantitatif, karena dalam penelitian ini ingin mengetahui apakah ada pengaruh antara kreativitas guru dalam pembelajaran daring terhadap hasil belajar siswa. Pendekatan yang digunakan adalah penelitian kuantitatif korelasional, mengumpulkan data berupa angka-angka melalui instrumen penelitian dan menganalisisnya menggunakan statistik. Kemudian berdasarkan hasil data tersebut mencari hubungan antara variabel $(\mathrm{X})$ dan variabel $(\mathrm{Y})$.

Penelitian ini dilakukan di SDN Kedung Waringin, yang berlokasi di Jalan Johar Gang Masjid No. 2 RT 005 RW 004 Kel. Kedung Waringin Kec. Tanah Sareal Kota Bogor. Dan waktu penelitian dilaksanakan pada bulan Maret 2021, Tahun Ajaran 2020/2021.

Populasi pada penelitian ini adalah seluruh siswa kelas VI di SDN Kedung Waringin Tanah Sareal Kota Bogor, yang berjumlah 70 orang. Melihat subyek yang terdapat pada penelitian kurang dari 100 maka peneliti memutuskan untuk menjadikan seluruh populasi sebagai sampel, yaitu 70 sampel.

Variabel dalam penelitian ini terdiri atas dua variabel, satu variabel bebas dan satu variabel terikat. Yaitu kreativitas guru dalam pembelajaran daring sebagai variabel bebasnya, sedangkan variabel terikatnya adalah hasil belajar siswa.

Teknik pengumpulan data yang digunakan pada penelitian ini yaitu wawancara, angket, dan dokumentasi. Untuk mengetahui data kreativitas guru dalam pembelajaran daring, peneliti melkukan penyebaran angket melalui Google Form kepada siswa kelas VI SDN Kedung Waringin Tanah Sareal dan untuk mengetahui hasil belajar siswa peneliti menggunaka dokumentasi daftar nilai Penilaian Tengah Semester Mata Pelajaran PAI, agar menghasilkan data yang relevan.

Dalam menganalisis data yang telah terkumpul dari hasil penelitian, maka peneliti menggunakan analisis korelasi menggunakan rumus product moment. Selanjutnya untuk mengetahui pengaruh variabel $x$ terhadap variabel $y$, harga $\mathrm{r}_{x y}$ dikonsultasikan dengan tabel interpretasi untuk mencari besarnya sumbangan 
1413 Pengaruh Kreativitas Guru Dalam Pembelajaran Daring Terhadap Hasil Belajar Siswa Pada Mata Pelajaran Pendidikan Agama Islam - Suhendra, Dian Nurbaeti, Syarifah Gustiawati

DOI: https://doi.org/10.31004/edukatif.v3i4.568

(kontribusi) variabel $x$ terhadap variabel $y$ menggunakan rumus KP (Nilai Koefisien Diterminan). Dan untuk mengetahui signifikansi pengaruh variabel $x$ terhadap variabel $y$ dilakukan pengujian signifikansi koefisien korelasi dengan menggunakan rumus uji t.

\section{HASIL DAN PEMBAHASAN PENELITIAN}

Pada bagian ini disajikan deskripsi data hasil penelitian, pengujian persyaratan analisis data penelitian, pengujian hipotesis dan pembahasan hasil penelitian. Dalam penelitian ini disajikan deskripsi data dari setiap variabel, hasilnya dapat dijelaskan sebagai berikut:

Berdasarkan hasil analisis data menunjukkan bahwa variabel Kreativitas Guru dalam Pembelajaran Daring (X) diperoleh skor tertinggi yang dicapai menurut persepsi siswa sebesar 76, dan skor terendah sebesar 37. Dari hasil perhitungan statistik diperoleh mean sebesar 67,41, median sebesar 69,50, mode sebesar 76, dan standar deviasi sebesar 7,762. Distribusi frekuensi variabel data Kreativitas Guru dalam Pembelajaran Daring dapat digambarkan dalam bentuk diagram berikut ini:

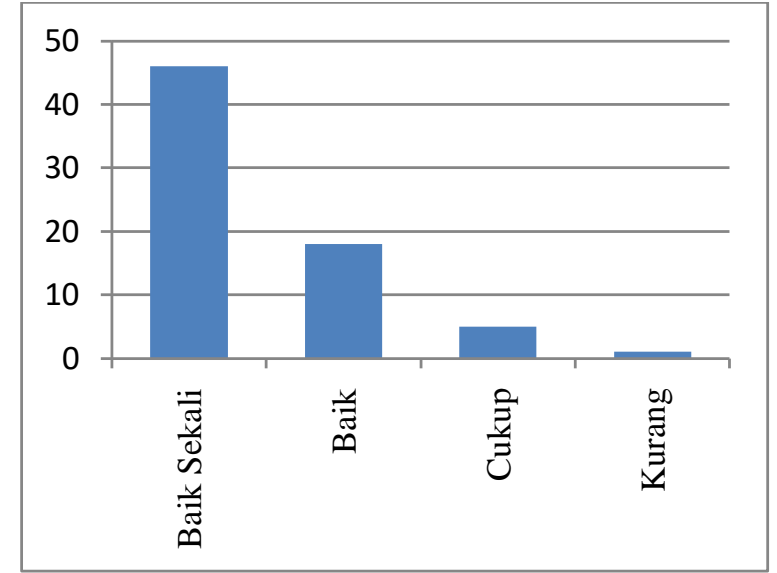

\section{Gambar 1. Distribusi Frekuensi Data Kreativitas Guru dalam Pembelajaran Daring}

Berdasarkan Gambar 1 tersebut, dapat dideskripsikan bahwa variabel Kreativitas Guru dalam Pembelajaran Daring (X) dari 70 siswa yang menjadi sampel, 46 siswa atau 65,72\% mengatakan kreativitas guru dalam pembelajaran daring baik sekali, 18 siswa atau $25,72 \%$ mengatakan kreativitas guru dalam pembelajaran daring baik, 5 siswa atau 7,14\% mengatakan kreativitas guru dalam pembelajaran daring cukup, dan 1 siswa atau 1,42\% mengatakan kreativitas guru dalam pembelajaran daring kurang. Dari diagram batang di atas menunjukkan, bahwa Kreativitas Guru dalam Pembelajaran Daring yang diukur menggunakan angket termasuk dalam kategori baik sekali yang ditunjukkan oleh persentase perolehan skor tersebut.

Berdasarkan data hasil belajar siswa yang diperoleh dari Penilaian Tengah Semester (PAS), dari 70 siswa menunjukkan bahwa nilai tertinggi yang dicapai oleh siswa sebesar 96 dan nilai terendah sebesar 54 . Dari hasil perhitungan statistik diperoleh mean sebesar 78,64, median sebesar 76,00, mode sebesar 76, dan standar deviasi sebesar 11,488. Distribusi frekuensi variabel data Hasil Belajar (Y) dapat dilihat pada diagram berikut ini: 
1414 Pengaruh Kreativitas Guru Dalam Pembelajaran Daring Terhadap Hasil Belajar Siswa Pada Mata Pelajaran Pendidikan Agama Islam - Suhendra, Dian Nurbaeti, Syarifah Gustiawati

DOI: https://doi.org/10.31004/edukatif.v3i4.568

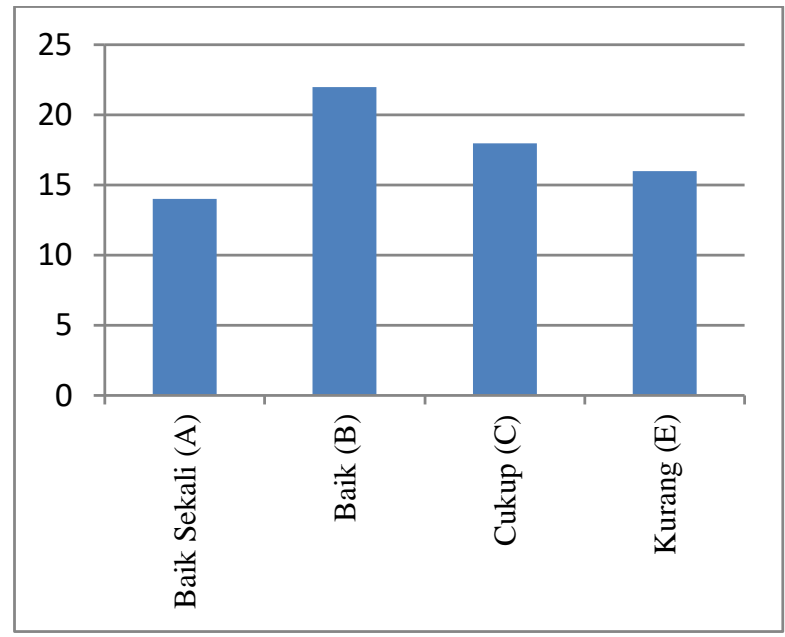

\section{Gambar 2. Distribusi Frekuensi data Hasil Belajar Siswa}

Berdasarkan Gambar 2 tersebut, dapat dideskripsikan bahwa pada variabel Hasil Belajar Siswa (Y) dari 70 siswa, 14 siswa atau 20\% memiliki hasil belajar baik sekali, 22 siswa atau 31,43\% memiliki hasil belajar baik, 18 siswa atau 25,71\% memiliki hasil belajar cukup, dan 16 siswa atau 22,86\% memiliki hasil belajar kurang. dari diagram dan tabel distribusi frekuensi data Hasil Belajar Siswa yang diukur menggunakan Penilaian tengah Semester pada mata pelajaran Pendidikan Agama Islam menunjukkan bahwa Hasil Belajar Siswa kelas VI di SDN Kedung Waringin dilihat dari distribusi frekuensi maupun rata-rata termasuk dalam kategori baik yang ditunjukkan oleh persentase nilai tersebut.

Untuk mengetahui apakah teknik analisis data dapat dilakukan atau tidak maka dapat diujikan dengan uji normalitas. Uji normalitas adalah sebuah uji yang dilakukan dengan tujuan untuk mengetahui apakah data yang diperoleh berasal dari populasi yang berdistribusi normal atau tidak dengan taraf signifikan $\alpha=0,05$. Uji normalitas ini menggunakan Kolmogrov-Smirov dengan bantuan IBM SPSS 26. Uji normalitas data ini dilakukan untuk uji t sebagai prasyarat analisis.

Tabel 1

Hasil Uji Normalitas

\begin{tabular}{|c|c|c|}
\hline \multicolumn{3}{|c|}{$\begin{array}{c}\text { One-Sample Kolmogorov- } \\
\text { Smirnov Test }\end{array}$} \\
\hline \multicolumn{2}{|l|}{$\mathrm{N}$} & 70 \\
\hline \multirow{2}{*}{$\begin{array}{l}\text { Normal } \\
\text { Parameters }\end{array}$} & Mean & .0000000 \\
\hline & $\begin{array}{l}\text { Std. } \\
\text { Deviation }\end{array}$ & $\begin{array}{r}11.39345 \\
186\end{array}$ \\
\hline \multirow{3}{*}{$\begin{array}{l}\text { Most Extreme } \\
\text { Differences }\end{array}$} & Absolute & .117 \\
\hline & Positive & .081 \\
\hline & Negative & -.117 \\
\hline \multicolumn{2}{|l|}{ Test Statistic } & .117 \\
\hline \multicolumn{2}{|c|}{ Asymp. Sig. (2-tailed) } & .019 \\
\hline \multicolumn{3}{|c|}{ a. Test distribution is Normal. } \\
\hline \multicolumn{3}{|c|}{ b. Calculated from data. } \\
\hline
\end{tabular}


1415 Pengaruh Kreativitas Guru Dalam Pembelajaran Daring Terhadap Hasil Belajar Siswa Pada Mata Pelajaran Pendidikan Agama Islam - Suhendra, Dian Nurbaeti, Syarifah Gustiawati

DOI: https://doi.org/10.31004/edukatif.v3i4.568

Setelah data Kreativitas Guru dalam Pembelajaran Daring dan Hasil Belajar Siswa kelas VI berhasil dikumpulkan, agar dapat membuktikan apakah hipotesis penelitian sesuai atau tidak dengan kenyataan yang sebenarnya dari hasil penelitian yang telah dilakukan, maka penulis akan melakukan uji korelasi dengan menggunakan rumus korelasi product moment.

Berdasarkan hasil analisis rumus product moment, menghasilkan nilai akhir $\mathrm{r}_{\text {hitung }}$ sebesar 0,406. Kemudian nilai tersebut diinterpretasikan dengan cara sederhana yaitu dengan memberikan interpretasi terhadap angka korelasi product moment. Setelah dilihat besarnya $r_{x y}$ yang diperoleh sebesar 0,406 terletak antara 0,40-0,699 dalam pedoman angka indeks $r_{\mathrm{xy}}$ atau " $\mathrm{r}$ " product moment. Ini berarti korelasi antara variabel $\mathrm{X}$ dan variabel $\mathrm{Y}$ terdapat pengaruh atau korelasi yang tergolong sedang atau cukup.

Berdasarkan hasil $r_{x y}$ dan nilai $r_{\text {tabel }}$ pada taraf signifikansi 5\%, diperoleh hasil masing-masing yaitu $r_{\text {hitung }}$ sebesar 0,406 dan $r_{\text {tabel }}$ sebesar 0,250. Dengan demikian bahwa nilai $r_{\text {hitung }}>$ rtabel $=0,406>0,250$. Hal ini menunjukkan bahwa Ha diterima dan Ho ditolak, artinya terdapat pengaruh yang signifikan antara kreativitas guru dalam pembelajaran daring $(\mathrm{X})$ terhadap hasil belajar siswa $(\mathrm{Y})$.

Selanjutnya untuk mengetahui seberapa besar pengaruh Kreativitas Guru dalam Pembelajaran Daring (X) terhadap Hasil Belajar Siswa (Y), peneliti melakukan analisis koefisien determinasi. Berdasarkan hasil koefisien detrminasi tersebut, diketahui KP sebesar 16,48\% sehingga dapat diketahui besarnya sumbangan (kontribusi) variabel kreativitas guru dalam pembelajaran daring $(\mathrm{X})$ terhadap variabel hasil belajar siswa (Y) adalah $16,48 \%$ dan sebesar $83,52 \%$ dipengaruhi oleh faktor lain.

Untuk mengetahui signifikansi pengaruh variabel $\mathrm{X}$ terhadap variabel $\mathrm{Y}$ dilakukan pengujian signifikansi koefisien korelasi dengan menggunakan rumus uji t. Berdasarkan hasil uji t tersebut, diperoleh nilai $t_{\text {hitung }}$ sebesar 3,663 dan nilai $t_{\text {tabel }}$ pada $\alpha=0,05$ sebesar 1,667. Dengan demikian $t_{\text {hitung }}>t_{\text {tabel }}=3,663>$ 1,667 artinya Ho ditolak dan Ha diterima yang berbunyi terdapat pengaruh yang signifikan antara kreativitas guru dalam pembelajaran daring terhadap hasil belajar siswa.

Pembahasan hasil penelitian ini akan mendeskripsikan hasil penelitian untuk menjawab rumusan masalah yang telah dibahas sebelumnya. Penelitian ini dilakukan untuk mengetahui adakah pengaruh yang signifikan antara kreativitas guru dalam pembelajaran daring terhadap hasil belajar siswa. Populasi dan sampel penelitian ini adalah seluruh siswa dari kelas VI SDN Kedung Waringin, yaitu 70 siswa.

Pendekatan yang dilakukan dalam penelitian ini merupakan pendekatan kuantitatif. Pengumpulan data dilakukan dengan teknik wawancara, angket (kuesioner), dan dokumentasi nilai PTS. Sedangkan teknik analisis datanya menggunakan teknik statistik yaitu menghitung korelasi product moment untuk mencari pengaruh antara kedua variabel, serta menghitung koefisien determinasi dan melakukan pengujian hipotesis.

Hasil temuan penelitian tentang kreativitas guru dalam pembelajaran daring dari hasil perhitungan analisis data variabel $\mathrm{X}$ menunjukkan bahwa $65,72 \%$ dari 70 siswa mengatakan kreativitas guru dalam pembelajaran daring termasuk dalam kategori baik sekali. Sedangkan untuk hasil belajar siswa dari hasil Penilaian Tengah Semester pada mata pelajaran Pendidikan Agama Islam diperoleh nilai rata-rata 78,64 jika diinterpretasikan nilai tersebut termasuk ke dalam kategori baik.

Hasil perhitungan koefisien korelasi antara variabel Kreativitas Guru dalam Pembelajaran Daring (X) dengan variabel Hasil Belajar Siswa $(Y)$ diperoleh nilai $r_{\text {hitung }}$ sebesar $=0,406$. Demikian jika dibanding nilai $r_{\text {hitung }}$ dengan nilai $r_{\text {tabel }}$, dengan mengambil taraf signifikansi $5 \%$ dan derajat kebebasan $n-2=70-2=68$. Maka terdapat hasil nilai $r_{\text {hitung }}>r_{\text {tabel }}=0,406>0,250$. Nilai korelasi ini jika diinterpretasikan pada nilai koefisien korelasi, maka dikategorikan sedang atau cukup tingkat pengaruhnya. Berdasarkan hasil tersebut maka dinyatakan bahwa ada pengaruh antara kreativitas guru dalam pembelajaran daring dengan hasil belajar siswa kelas VI pada mata pelajaran Pendidikan Agama Islam di SDN Kedung Waringin.

Selanjutnya peneliti mencari seberapa besarkah koefisien determinasi. Berdasarkan rumus tersebut, terdapat hasil hitungan sebesar 16,48\%. Dapat disimpulkan bahwa kreativitas guru dalam pembelajaran daring memberikan kontribusi (sumbangan) terhadap hasil belajar siswa sebesar 16,48\%, dan sisanya 83,52\% 
1416 Pengaruh Kreativitas Guru Dalam Pembelajaran Daring Terhadap Hasil Belajar Siswa Pada Mata Pelajaran Pendidikan Agama Islam - Suhendra, Dian Nurbaeti, Syarifah Gustiawati

DOI: https://doi.org/10.31004/edukatif.v3i4.568

ditentukan oleh faktor lain. Kemudian berdasarkan pengujian signifikansi koefisien korelasi dengan menggunakan rumus uji $\mathrm{t}$ diperoleh nilai $\mathrm{r}_{\text {hitung }}$ sebesar 3,663 dan nilai $\mathrm{t}_{\text {tabel }}$ pada $\alpha=0,05$ sebesar 1,667. Dengan demikian $t_{\text {hitung }}>t_{\text {tabel }}=3,663>1,667$ sehingga diketahui bahwa terdapat pengaruh yang signifikan antara kreativitas guru dalam pembelajaran daring terhadap hasil belajar siswa.

Sudah banyak penelitian yang mengkaji tentang kreativitas guru, seperti penelitian yang dilakukan oleh (Suharianti, 2017) yang menyatakan terdapat hubungan yang positif dan signifikan antara kreativitas guru dalam mengajar dengan hasil belajar siswa. Penelitian lain dilakukan oleh (Sari, 2018) yang menyatakan bahwa ada pengaruh antara kreativitas guru dalam pembelajaran terhadap hasil belajar. Penelitian yang dilakukan oleh (Noviantari, 2017) menyatakan bahwa kreativitas guru berpengaruh positif terhadap minat belajar siswa. Selanjutnya penelitian lain yang dilakukan oleh (Arnawati, 2018) yang menyatakan terdapat pengaruh positif yang signifikan antara kreativitas guru dalam mengelola pembelajaran ekonomi dan motivasi belajar peserta didik. Sedangkan dalam penelitian ini peneliti memfokuskan pada proses pembelajaran daring, yang mana kreativitas guru dalam pembelajaran daring berpengaruh signifikan pada hasil belajar. Penelitian terdahulu yang telah disebutkan adalah dalam rangka sebagai pendukung terkait dengan kumpulan teori, dan referensi agar penelitian yang dilakukan menjadi semakin kokoh, karena isi yang terdapat pada masingmasing jurnal dapat dijadikan acuan.

Berdasarkan pada pengalaman peneliti dalam proses penelitian ini, ada beberapa keterbatasan yang ditemukan. Karena penelitian ini sendiri tentu memiliki kekurangan yang perlu terus diperbaiki. Beberapa keterbatasan dalam penelitian ini, antara lain: (1) Jumlah responden yang hanya 70 orang, tentunya masih sangat kurang untuk menggambarkan keadaan yang sebenarnya (2) Variabel terikat penelitian ini hanya difokuskan pada kreativitas guru saja yaitu salah satu dari beberapa faktor yang dapat mempengaruhi hasil belajar, yang mana terdapat faktor lain yang dapat mempengaruhi hasil belajar siswa (3) Dalam proses pengambilan data kreativitas guru, informasi yang diberikan responden melalui angket terkadang tidak menunjukkan pendapat responden yang sebenarnya.

\section{KESIMPULAN}

Kreativitas guru dalam pembelajaran daring pada mata pelajaran Pendidikan Agama Islam kelas VI SDN Kedung Waringin yang diukur menggunakan angke termasuk kategori baik sekali. Dan hasil belajar siswa kelas VI di SDN Kedung Waringin dilihat dari distribusi frekuensi maupun rata-rata termasuk dalam kategori baik. Data menunjukkan interpretasi tingkat reliabilitas tinggi besarnya pengaruh kreativitas guru dalam pembelajaran daring terhadap hasil belajar siswa di dapat $t_{\text {hitung }}=3,663$ dan $t_{\text {tabel }}=1,667$, dengan taraf signifikan 0,05 berarti Ha diterima dan Ho ditolak, ini dapat disimpulkan bahwa bahwa terdapat pengaruh yang signifikan antara kreativitas guru dalam pembelajaran daring terhadap hasil belajar siswa.

\section{UCAPAN TERIMA KASIH}

Jazakumullah khairan katsiran kepada semua pihak yang sudah memberikan bimbingan dan bantuan baik itu secara langsung maupun secara tidak langsung, baik dari segi moril maupun materil yang tidak bisa penulis sebutkan satu-persatu. Semoga Allah membalas dengan kebaikan yang berlipat ganda

\section{DAFTAR PUSTAKA}

Ambarita, J., \& Yuniati, E. (2021). PAK dan COVID-19 Problematika Pembelajaran PAK Daerah Tertinggal. Penerbit Adab.

Anwar, M. (2018). Menjadi Guru Profesional. Prenadamedia Group.

Arnawati. (2018). Pengaruh Kreativitas Guru dalam Mengelola Pembelajaran Ekonomi Terhadap Motivasi Belajar Peserta Didik di SMA Negeri 11 Sinjai [Universitas Negeri Makassar]. http://eprints.unm.ac.id 
1417 Pengaruh Kreativitas Guru Dalam Pembelajaran Daring Terhadap Hasil Belajar Siswa Pada Mata Pelajaran Pendidikan Agama Islam - Suhendra, Dian Nurbaeti, Syarifah Gustiawati

DOI: https://doi.org/10.31004/edukatif.v3i4.568

Dimyati, A. (2019). Pengembangan Profesi Guru. Gre Publishing.

Fahrina, A., Amelia, K., \& Zahara, C. R. (2020). Minda Guru Indonesia: Pandemi Corona, Disrupsi Pendidikan dan Kreatifitas Guru. Syiah Kuala University Press. http://www.unsyiahpress.unsyiah.ac.id

Fitrianingtyas, A., \& Radia, E. H. (2017). Peningkatan Hasil Belajar IPA Melalui Model Discovery Learning Siswa Kelas IV SDN Gedanganak 02. Jurnal Mitra Pendidikan, 1(6), 708-720.

Murdiana, Jumri, R., \& Damara, B. E. P. (2020). Pengembangan Kreativitas Guru dalam Pembelajaran Matematika. Jurnal Pendidikan Matematika Raflesia, 05(02), 153-160. https://ejournal.unib.ac.id/index.php/jpmr

Nafrin, I. A., \& Hudaidah, H. (2021). Perkembangan Pendidikan Indonesia di Masa Pandemi Covid-19. Edukatif: Jurnal Ilmu Pendidikan, 3(2), 456-462. https://doi.org/10.31004/edukatif.v3i2.324

Noviantari, N. (2017). Pengaruh Kreativitas Guru Terhadap Minat Belajar Siswa di SD Muhammadiyah 09 Malang [Universitas Islam Negeri Maulana Malik]. http://etheses.uin-malang.ac.id

Oktaria, T. A., \& Jaenudin, R. (2017). Pengaruh Kreativitas Mengajar Guru terhadap Hasil Belajar Siswa pada Mata Pelajaran Ekonomi di SMA N 1 Muara Padang Banyuasin Sumatera Selatan. JUrnal Profit, 4(2), 145-154. https://ejournal.unsri.ac.id/index.php/jp/article/view/5593

Oktavia, Y. (2014). Usaha Kepala Sekolah dalam Meningkatkan Kreativitas Guru dalam Pembelajaran di Sekolah Dasar. Jurnal Administrasi Pendidikan, 2(1), 808-831. https://ejournal.unib.ac.id/index.php/jpmr

Pentury, H. J. (2017). Pengembangan Kreativitas Guru dalam Pembelajaran Kreatif Pelajaran Bahasa Inggris. Jurnal Ilmiah Kependidikan, 4(3), 265-272.

Sari, S. M. (2018). Pengaruh kreativitas Guru dalam Pembelajaran Terhadap Hasil Belajar Mata Pelajaran Pendidikan Agama Islam Peserta Didik Kelas VIII SMP Negeri 3 Batanghari [Institut Agama Islam Negeri Metro]. https://repository.metrouniv.ac.id

Suharianti. (2017). Pengaruh Kreativitas Guru dalam Mengajar Terhadap Hasil Belajar Siswa Pada Mata Pelajaran Sejarah Kebudayaan Islam di Madrasah Tsanawiyah Negeri Tanjung Morawa [Universitas Islam Negeri Sumatera Selatan]. https://repository.uinsu.ac.id

Sutrisno. (2021). Meningkatkan Minat dan Hasil Belajar TIK Materi Tipologi Jaringan dengan Media Pembelajaran. Ahlimedia Press.

Syahputra, E. (2020). Snowball Throwing Tingkatkan Minat dan Hasil Belajar. Haura Publishing.

Wahyuningsih, E. S. (2020). Model Pembelajaran Mastery Learning Upaya Peningkatan Keaktifan dan Hasil Belajar Siswa. Deepublish.

Yunitasari, R., \& Hanifah, U. (2020). Pengaruh Pembelajaran Daring terhadap Minat Belajar Siswa pada Masa COVID 19. Edukatif: Jurnal Ilmu Pendidikan, 2(3), 232-243.

https://doi.org/10.31004/edukatif.v2i3.142 